\title{
VERA CHAIA
}

Lideranças

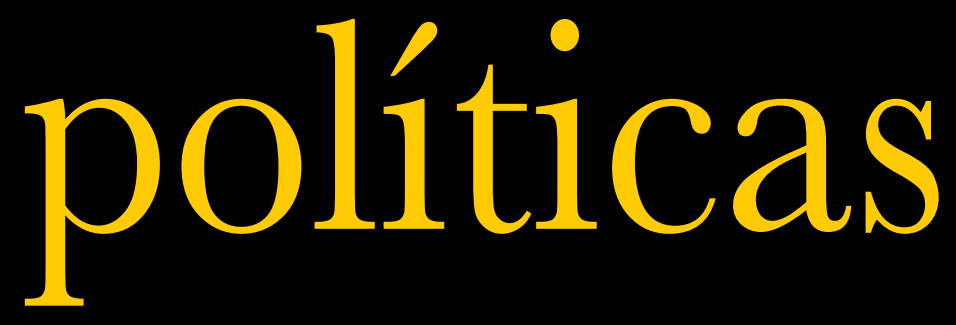

e cinema:

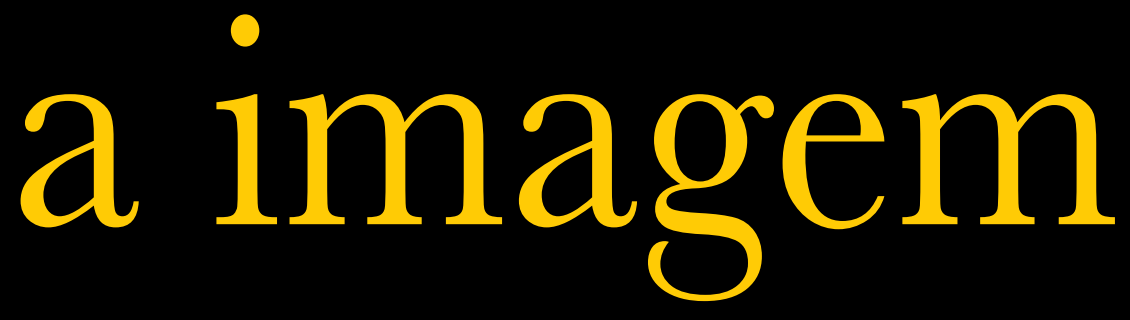

construída 


\section{RESUMO}

O presente ensaio tem como objetivo analisar a temática das lideranças políticas e cinema, buscando compreender como alguns governantes brasileiros são retratados em documentários realizados no país.

O cinema brasileiro possui uma história muito limitada de trabalhar comfilmes que reproduzem a história dos governantes. Somente nos anos 1970 é que começaram a ser produzidos, de maneira mais sistemática, filmes que buscam compreender a ação desses políticos nos períodos em que governaram o Brasil. Os filmes ou são laudatórios, pois exaltam a figura do governante, ou são críticos, por apresentarem determinados presidentes como incapazes.

Palavras-chave: lideranças políticas, cinema, presidentes, documentário, Brasil.

\section{ABSTRACT}

This essay seeks to analyze the theme of political leaders as depicted in movies. It aims at understanding how some Brazilian rulers are portrayed in documentaries made in the country. Brazilian cinema has had a limited history as regards the production of movies representing the history of the rulers of the country. It was not before the 1970s that movies began to be produced more systematically, and with the intention of understanding the actions of those politicians during their terms in office in Brazil. The films are either laudatory, when praising the figure of the ruler; or critical, when depicting some presidents as unqualified.

Keywords: political leaders, cinema, presidents, documentary, Brazil. 


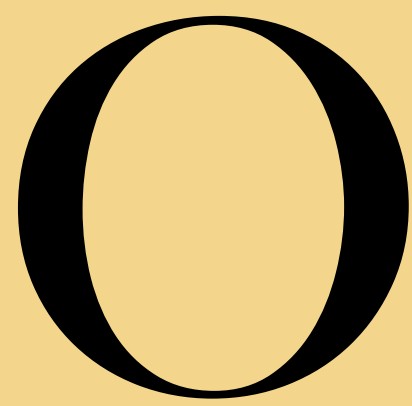

presente ensaio tem como objetivo analisar a temática das lideranças políticas e cinema, buscando compreender como alguns governantes brasileiros são retratados em documentários em períodos conturbados, considerando que a normalidade democrática de troca de poder é relativamente nova na história do país.

A produção brasileira de filmes que reproduzem a história dos governantes é recente e muito pequena. Somente nos anos 1970 é que começaram a ser produzidas, de maneira mais sistemática, películas que buscavam compreender a ação desses políticos nos períodos em que governaram o Brasil.

A dimensão política do cinema explicita-se quando elege como tema de seus filmes de ficção e/ou documentários as lideranças políticas, criando e disseminando determinadas perspectivas que abordam os governantes do país, construindo imagens públicas que passam a fazer parte do imaginário político. Nesse sentido, o cinema corrobora o aparecimento do personalismo na cultura política nos tempos atuais, pois ele é marcado por uma série de concepções que influenciam a própria prática política. Deposita-se fé no indivíduo, como se essa autoridade pudesse resolver todos os problemas da nação brasileira. É valorizado o prestígio pessoal, a capacidade individual, como se um indivíduo fosse capaz de levar avante sozinho um projeto de governo.

O que prevalece nesse tipo de visão é a ideia de que o Estado, identificado com o Executivo, resolve todos os problemas, atende aos "necessitados", ocorrendo, portanto, uma supervalorização do Executivo e do governante.

O personalismo traz em si mesmo um traço perverso, pois desqualifica as organizações democráticas, desvaloriza as instituições, prevalecendo nesses estilos de liderança política um traço autoritário. Essa concepção do personalismo na cultura política
Trabalho financiado pelo $\mathrm{CNPq}$ - Bolsa Produtividade em Pesquisa (PQ). Este texto é parte da pesquisa que estamos realizando, a qual abrange não só os filmes nacionais, mas tambéma filmografia produzida nos Estados Unidos relacionada ao tema. Pesquisa em andamento. 
também pode contribuir para uma visão elitista, pois somente algumas pessoas possuiriam qualificações adequadas para governar.

Tomando como referência a mencionada produção, podem-se analisar algumas lideranças políticas a partir de Getúlio Vargas. Para isso, serão abordados alguns documentários que retrataram governantes a partir da descrição e contextualização destes, incorporando alguns discursos políticos que marcaram seus governos e avaliando como esses discursos se reportaram ao povo brasileiro.

Vários documentários e filmes de ficção brasileiros apresentaram políticos retratados como heróis (Getúlio Vargas, filme de Ana Carolina Teixeira Soares) ou como farsantes (Jânio a 24 Quadros, filme de Luís Alberto Pereira). Silvio Tendler é o diretor que mais realizou filmes focado nas lideranças políticas - Os Anos JK, Jango e Tancredo Neves. João Moreira Salles também se destaca por ter dirigido o filme Entreatos, assim como Eduardo Coutinho, que realizou o filme $O s$ Peões, abordando a origem sindical de Luiz Inácio Lula da Silva, e Fabio Barreto, que dirigiu Lula, Filho do Brasil.

Foram selecionados para a presente análise Getúlio Vargas, Juscelino Kubitschek e João Goulart. Os três documentários estão conectados e relacionados entre si porque as trajetórias políticas desses governantes se cruzam em vários momentos de nossa história.

Getúlio Vargas toma posse em 3 de novembro de 1930, instaura o Estado Novo em novembro de 1937 e é deposto em 1945. Retornando ao poder em 1951, suicida-se em 24 de agosto de 1954. É no período do Estado Novo (1937-45), em que todas as casas legislativas são fechadas e as eleições para todos os cargos executivos são suspensas, que Vargas nomeia Juscelino Kubitschek prefeito de Belo Horizonte. João Goulart, por sua vez, teve sua carreira política vinculada ao governo Vargas e ao PTB (Partido Trabalhista Brasileiro) e foi ministro do Trabalho no período de 1950 a 1954, durante a segunda gestão presidencial de Vargas. Juscelino Kubitschek, após o suicídio de Getúlio Vargas, foi candidato pelo PSD (Partido Social Democrata) e concorreu à presidência da República; seu vice foi João Goulart, eleito pelo PTB.

Getúlio Vargas se suicidou após sofrer pressões das Forças Armadas e de setores da sociedade brasileira, incluindo a imprensa, que desencadeou uma campanha feroz contra esse governante. Juscelino Kubitschek morreu num acidente de carro pouco explicado e com muitas dúvidas sobre as circunstâncias de sua morte. João Goulart foi derrubado pelos militares no dia 31 de março de 1964 e, após exílio forçado, também morreu em circunstâncias duvidosas, segundo seus seguidores e familiares. Os filmes sobre Getúlio Vargas, Juscelino Kubitschek e Jango foram produzidos durante o regime militar (1964-85). Quais são as características dramáticas dessas lideranças?

Para análise dos filmes serão adotados os seguintes procedimentos metodológicos e de pesquisa: a) análise interna dos filmes selecionados que tratam do tema liderança política/poder executivo; b) análise histórica da trajetória das lideranças retratadas nos filmes, bem como análise das questões institucionais, do comportamento político e da comunicação política no período abordado; c) vinculação orgânica entre a análise interna dos filmes e situação político-cultural da época retratada.

\section{GETÚLIO VARGAS:}

\section{A IMAGEM DE UM GOVERNANTE INJUSTIÇADO}

O filme Getúlio Vargas foi dirigido por Ana Carolina Teixeira Soares, no ano de 1974, e retrata a figura política de Getúlio Vargas, desde a Revolução de 1930 até o seu suicídio em 1954. Adiretora recupera trechos de filmes produzidos pelo Departamento de Imprensa e Propaganda (DIP), órgão criado por Getúlio durante a sua primeira gestão, que tinha 
como objetivo divulgar as realizações do governo federal.

A diretora também utilizou materiais filmados nas décadas de 1920 a 1950 . $\mathrm{Na}$ avaliação de Cláudio Aguiar Almeida (Almeida, 2007, p. 41), faz-se necessário "problematizar a categoria de 'filme documentário' a partir de algumas considerações de Jean-Claude Bernardet e Alcides Freire Ramos". Nolivro Cinema e História do Brasil, Jean-Claude Bernardet e Alcides Freire Ramos apontam as dificuldades de se conceituar o "filme documentário", definindo-o como "filmagens de algo que aconteceria independentemente da realização de um filme.Por exemplo: um jogo de futebol ocorre independentemente de ser filmado ou não, ao passo que, no caso de um filme de ficção, o que é filmado é preparado e representado especialmente para a filmagem". Os limites dessa definição, construída em oposição ao filme de ficção, ficam bastante claros quando Alcides e Jean-Claude destacam os recursos e as estratégias mobilizados pelos cineastas para imprimir sentidos e significados às suas obras. Se os eventos captados pela câmera cinematográfica durante as filmagens de um documentário não são, pelo menos hipoteticamente, "preparados" e "representados", o produto final do trabalho do cineasta - o filme - é resultado de diversas manipulações que definem sua forma final. Por meio da escolha rigorosa de enquadramentos de câmera, seleção de imagens, montagem, inserção de entrevistas, diálogos, comentários, músicas e outros elementos que vão compor a trilha sonora, os documentaristas "constroem uma interpretação da realidade" (Bernardet e Ramos, 1988, pp. 36-7) chegando mesmo, em alguns casos específicos, a construir ou falsificar a realidade que se pretende documentar (Almeida, 2007, p. 41).

O documentário de Ana Carolina assume uma postura favorável à figura política de Getúlio Vargas. A primeira cena é do enterro do presidente e a leitura de sua carta testamento, documento que explica as razões de seu suicídio. Selecionamos as partes mais contundentes da carta, lida no documentário, a qual Vargas escreve em primeira pessoa e afirma que o tudo que fez, como governante, foi em nome do povo:

"Mais uma vez, as forças e os interesses contra o povo coordenaram-se novamente e se desencadeiam sobre mim.

Não me acusam, insultam; não me combatem, caluniam e não me dão o direito de defesa. Precisam sufocar a minha voz e impedir a minha ação, para que eu não continue a defender, como sempre defendi, o povo e principalmente os humildes. Sigo o destino que me é imposto.

[...] Meu sacrifício vos manterá unidos e meu nome será a vossa bandeira de luta. Cada gota de meu sangue será uma chama imortal na vossa consciência e manterá a vibração sagrada para a resistência.Ao ódio respondo com o perdão. E aos que pensam que me derrotaram respondo com a minha vitória. Era escravo do povo e hoje me liberto para a vida eterna. Mas esse povo de quem fui escravo não mais será escravo de ninguém. Meu sacrifício ficará para sempre em sua alma e meu sangue será o preço do seu resgate.

Lutei contra a espoliação do Brasil. Lutei contra a espoliação do povo. Tenho lutado de peito aberto. O ódio, as infâmias, a calúnia não abateram meu ânimo. Eu vos dei a minha vida. Agora ofereço a minha morte. Nada receio. Serenamente dou o primeiro passo no caminho da eternidade e saio da vida para entrar na história.

\section{Getúlio Vargas}

Rio de Janeiro, 24 de agosto de 1954."

Após mostrar cenas do enterro de Getúlio Vargas, a diretora faz uma retrospectiva da vida política do ex-presidente, desde o período da posse até o suicídio. Todas as imagens e os trechos de discursos que aparecem no filme ressaltam e idolatram Vargas: grandes retratos em locais públicos e músicas compostas especialmente para o documentário. Jards Macalé é um dos compositores e, em uma de suas canções, ele exalta a figura do governante, mesmo após o Golpe do Estado Novo, período conhecido por suas características ditatoriais: "Getúlio 
Vargas não tem defeito... e naquele Estado Novo foi o chefe enraizado... [parte da letra musical de Jards Macalé]".

Um aspecto fundamental do documentário Getúlio Vargas é o fato de Ana Carolina se apropriar, em grande parte, dos documentários produzidos pelo DIPdurante o governo Vargas. Assim, as imagens do filme são originadas de diversas peças de propaganda governamental. Por sua vez, Ana Carolina monta o filme sobre um áudio próprio e um encadeamento de imagens (montagem) de sua autoria.

Nesse sentido, assiste-se a imagens de Getúlio Vargas em grandes manifestações, em festas cívicas nas ruas, e em todas as cenas são executadas, exaustivamente, marchas militares. Em uma dessas festas cívicas, Vargas aparece sendo enaltecido por um coro infantil, e um canto cantado in off reproduz as seguintes palavras: "Presidente leal e bondoso é Getúlio o nosso protetor, paras crianças ele é o amigo, para o futuro que ele chamou...".

Ao som do canto vemos um enorme painel com o retrato de Getúlio Vargas. O uso de crianças cantando, marchando e vestidas com uniforme de escoteiros também é uma constante. Passa-se a ideia do futuro do Brasil, com a formação dos novos cidadãos e, ao fundo, aparecem retratos de Vargas e da bandeira brasileira.

Como as cenas do documentário de Ana Carolina são peças de propaganda produzidas pelo DIP, o filme é todo pontuado por festas e cerimônias militares. Também aparecem estádios de futebol, como o de São Januário, com uma partida clássica Fla-Flu (Flamengo e Fluminense) - cuja narração exalta o trabalho e o jogo coletivo, pois, sem o auxílio de uma equipe, o jogo fica desequilibradoe sem chances de vitória para o time que opta por jogadas individuais .

Getúlio Vargas surge em várias situações, sempre sorrindo, inaugurando ou visitando obras públicas ou setores de produção apoiados pelo governo federal. O filme (sonora e visualmente) exalta uma figura do político brasileiro, mostrando um presidente dinâmico, empreendedor e amado pelo povo.Além de cerimônias mili- tares, destaca-se a presença de militares que acompanham Vargas em suas peregrinações, sempre com marchas militares.

Para mostrar as realizações do governo, aparecem obras do Vale do Rio Doce, produções e fazendas experimentais, Petrobras, Indústria de Ferro e Aço, reforma do porto do Rio de Janeiro e o movimento deste, com a saída de mercadorias brasileiras exportadas.

Trata-se, portanto, da geração de imagens produzidas para expressarem o potente desenvolvimento econômico e social do Brasil. D. Alzira Vargas, primeira-dama, distribui brinquedos para as crianças numa celebração natalina. Getúlio Vargas aparece logo em seguida, jogando pacotinhos, da sacada de um prédio, para a multidão que o aplaude efusivamente.

Chegando a um momento de tensão cinematográfica (e da realidade), Getúlio é obrigado a sair da presidência. O documentário não explica direito as razões, pois logo em seguida vemos o general Eurico Gaspar Dutra,ex-ministro daGuerrade Getúlio, sendo eleito presidente da República pelo PSD (Partido Social Democrata) no ano de 1945.

Getúlio Vargas é eleito senador por dois estados. O documentário avança no tempo para o ano de 1950 , ocasião em que o político foi eleito presidente do Brasil. As cenas mais marcantes são cenas de sua campanha eleitoral, com palanques lotados de políticos e autoridades e com multidões prestigiando o candidato. Numa das cenas discursa, dando o tom de sua campanha eleitoral:

“Quanto a vós trabalhadores, o que vos tenho a dizer é que eu tenho sido um dos homens mais traídos, mais negados, mais injuriados por ter amparado os desprotegidos da sorte, por ter amparado os trabalhadores. E por isso mesmo sempre que saio no seio desses trabalhadores eu me ergo reconfortado pela sua solidariedade e pelo seu entusiasmo".

Após essa fala, o povo que assiste ao comício grita entusiasticamente: "Getúlio, Getúlio”. O discurso prossegue: "Nunca, nunca me arrependi do que fiz pelos trabalhadores. Só tenhoum cravo no meu coração 
que é de não ter feito por eles tudo o que desejava fazer".

Todo discurso de Vargas começava com o lema: “Trabalhadores do Brasil”. Sua fala agora ressalta a volta do regime democrático, como direito dos trabalhadores.

Após a sua posse como novo presidente do Brasil, são retomadas as cerimônias cívicas e desportivas. A cena mais marcante desse segundo período é sua entrada no estádio de futebol em carro aberto, sendo ovacionado pelos trabalhadores ali presentes, que comemoravamo dia $1^{\circ}$ de maio, Dia do Trabalho. O que mais se destaca nessa cena é a presença de um de seus assessores, que reproduz o começo do discurso, apenas movimentando os lábios no momento correto do discurso, e que parece ser o seu ghost-writer.

Em outra cena destaca-se o encontro entre trabalhadores e o novo presidente e, in off, surge a voz de Vargas: "[...] linguagem simples, leal e franca que sempre vos falo". O discurso de Getúlio Vargas enfatiza que vivemos agora uma verdadeira democracia social e econômica. Ele critica a "democracia política que desconhece a desigualdade social". Na sua avaliação o Brasil naquele período era diferente e salienta que a imprensa teria liberdade de criticar o governo. Voz in off do locutor reproduz o discurso do presidente: “Apelo à União Nacional. Não quero governar sem oposição porque entendo que sem crítica livre não há democracia. Não pretendo o silêncio e muito menos omissão. Colaboração não implica servidão, nem importa em abdicação".

Os discursos foram se radicalizando e mostrando a imagem de um governante nacionalista e que defendia uma orientação trabalhista: "Hoje estais com o governo, amanhã sereis governo".

A oposição estava se organizando e procurava desestabilizar o governo Vargas. Ocorre um atentado contra Carlos Lacerda, jornalista e líder da oposição, e quem morre é o seu acompanhante e segurança, major Vaz. É preso o guarda-costas de Vargas, acusado de executar o atentado: o documentário mostra essa conjuntura em cortes rápidos, acelerando o tempo.
Getúlio Vargas fica isolado politicamente, e ele já havia manifestado a sua opção: prefere sair morto a ser derrubado pela oposição. Getúlio se suicida. Novamente aparecem imagens de Vargas na urna funerária, rodeado de populares e de autoridades políticas. Não se ouvem as vozes, somente uma canção: “Grande Deus lá nas alturas, eterno pai tão clemente. Lá no vosso paraíso espera cheio de riso o nosso bom Presidente; eterno Pai tão clemente".

Outra canção é ecoada até o final dos letreiros do documentário: "Getúlio foi outro Cristo, com uma bala sublime. Todo povo brasileiro tem o coração trancado por saber tristonhamente que o nosso Presidente morrera suicidado".

As últimas canções e manifestações corroboram a imagem pública de um presidente que foi injustiçado e que deve ser sublimado pelo povo brasileiro. $\mathrm{O}$ mito Getúlio Vargas é perpetuado nas falas, nas imagens e nas canções.

\section{JUSCELINO KUBITSCHEK: O CONCILIADOR}

O filme $O s$ Anos $J K$ foi realizado por Silvio Tendler em 1980 e apresenta a trajetória do presidente Juscelino Kubitschek (1902-76), desde sua estreia como político, passando pela construção de Brasília e indo até a perda de seus direitos políticos.

O documentário, utilizando-se de imagens de arquivos descritos ao final do filme, inicia-se com a notícia da elaboração de uma nova Constituição Brasileira, a de 1946. Nessas cenas surgem como protagonistas os congressistas Luís Carlos Prestes (PCB) e Getúlio Vargas (PTB). Também são mostradas imagens do então presidente general Dutra e retomadas cenas da queda de Vargas, o período do Estado Novo e a ação dos militares.

O começo do documentário é bastante didático, mas com um posicionamento político explícito do diretor Silvio Tendler, ao criticar a cassação dos parlamentares do 
PCB efetuada após o começo da Guerra Fria, que consistiu no confronto político entre os EUA e a URSS, a partir de 1947.

Juscelino Kubitschek também é congressista na Constituinte de 1946 e, após dez anos de intensa vida política, é eleito presidente da República em 1955. O seu vice é João Goulart, que havia sido ministro do Trabalho na segunda gestão de Getúlio Vargas.

Uma música do cancioneiro popular virou símbolo de Juscelino Kubitschek e foi exaustivamente tocada: "O nono é o
Capa do DVD Os Anos JK, de Silvio Tendler timoneiro. Como pode o peixe vivo viver fora d'água fria. Como poderei viver, como poderei viver sem a tua, sem a tua, sem a tua companhia".
Reprodução

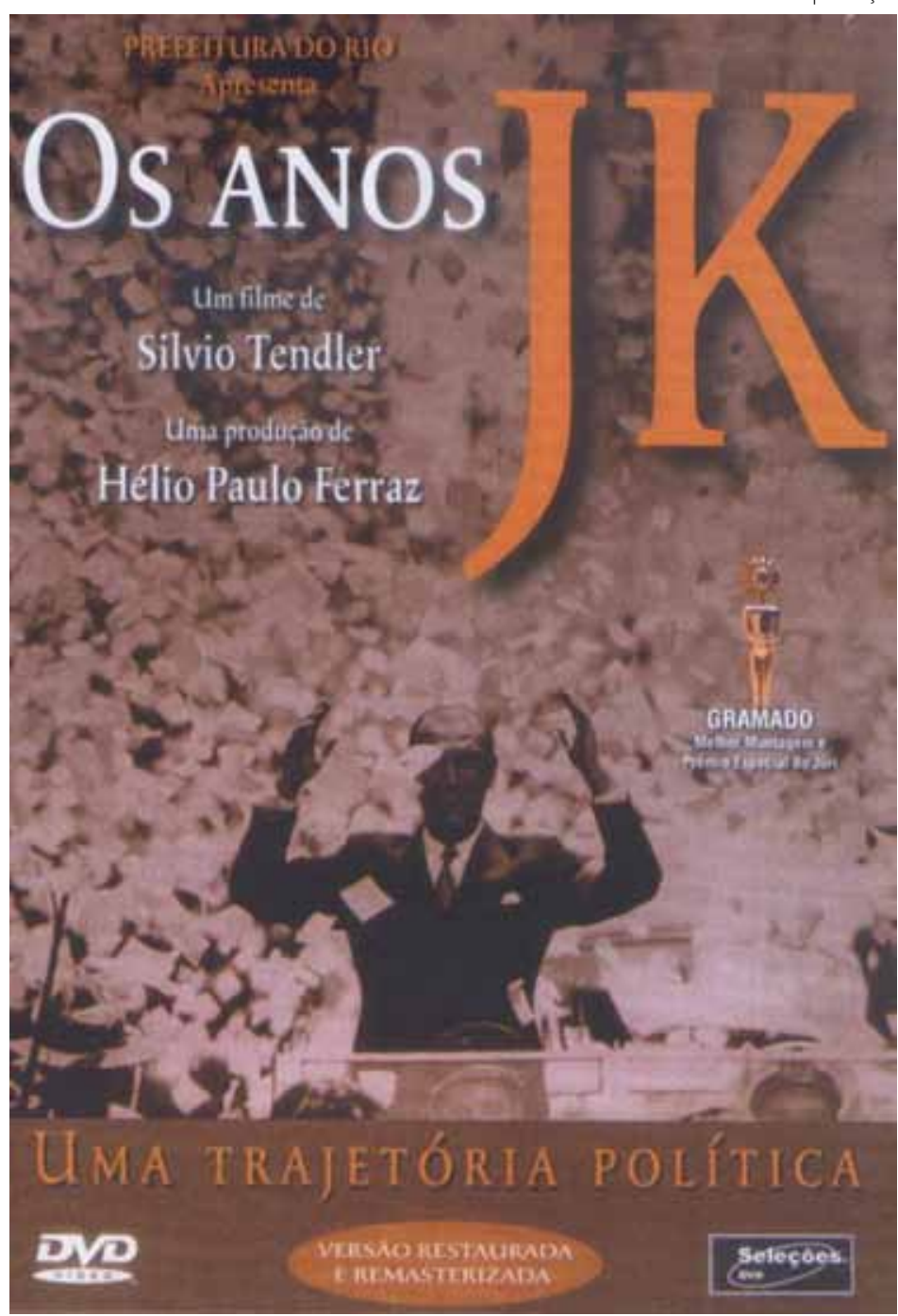

Juscelino Kubitschek construiu a sua carreira política no estado de Minas Gerais, onde foi militare médico. Exerceu os cargos de prefeito de Belo Horizonte - nomeado pelo então governador de Minas Gerais, Benedito Valadares (1940-45) - , governador de Minas Gerais - eleito pelo voto direto (1951-55) - e deputado federal.

Novamente aparecem imagens de Getúlio Vargas e de sua vitória eleitoral em 1950 e a vitória de Juscelino Kubitschek para o governo de Minas Gerais. O suicídio de Vargas é retomado, e Tancredo Neves, entrevistado na ocasião da feitura do documentário, relata o porquê desse ato (voz in off): “Getúlio fora vítima de quem combatia as suas qualidades, não os seus defeitos".

São apresentadas imagens do povo em revolta após o suicídio de Vargas e de Café Filho assumindo a presidência.

Cabe acrescentar, para melhor compreensão do filme, que Juscelino Kubitschek, pertencente à ala renovadora do PSD, foi eleito presidente em 1955 e obteve $36 \%$ dos votos. Café Filho e militares se opuseram a que Juscelino assumisse a presidência, argumentando que ele não havia sido eleito pela maioria dos votos. Porém, essa argumentação era casuística, pois em outros momentos a regra de maioria absoluta não havia sido aceita. O general Henrique Lott, após uma série de confrontos com os setores que faziam oposição à posse de Juscelino, conseguiu assegurar sua posse.

Juscelino Kubitschek reagiu ao discurso de Café Filho contra-argumentando:

"Não é verdade o que afirma o presidente da República. O presidente da República está mentido... [e depois repete a frase] Já disse que Deus me poupou o sentimento de medo e isto me leva a continuar com a bandeira na minha mão e esta irá até o Catete, a menos que me matem no meio da jornada".

Reproduzimos um trecho selecionado do discurso de Juscelino Kubitschek e que nos ajuda a compreender a postura política conciliadora que procurará exercer durante todo o seu período presidencial: 
"Discurso de Juscelino Kubitschek de

Oliveira na diplomação no TSE em 27 de janeiro de 1956

Recebendo das mãos de vossa excelência, senhor ministro presidente do Tribunal Superior Eleitoral, os diplomas de presidentee vice-presidente da República, experimentamos uma sensação ao mesmo tempo de júbilo e de terrível responsabilidade. O júbilo vem de ter tido desenvolvimento pacífico e legal a crise brasileira; quanto à temerosa responsabilidade, estão na consciência de todos os inúmeros problemas que tem de enfrentar quem vai governar este país.

Jubilosos estamos, senhor ministro presidente, porque de agora em diante sabemos melhor, por uma extraordinária experiência vivida, o quanto é difícil desrespeitar a lei; aprendemos todos nós como é poderosa a força da Justiça, a que todos devemos submeter-nos, desde os mais graduados aos mais humildes.

[...] Agradeço, em meu nome e em nome do eminente companheiro doutor João Goulart, a vossas excelências, srs. ministros, o exemplo de isenção, de imparcialidade, de rigorosa austeridade dado ao país. O segredo do equilíbrio e do prestígio deste Tribunal, a que a civilização brasileira deve mais um grande serviço, reside em duas virtudes fundamentais - a prudência e a altivez, que caracterizam os magistrados brasileiros. São Vossas Excelências prudentes, cautelosos, invariavelmente atentos na defesa da Justiça - e do direito.

[...] Pedimos a Deus que nos inspire e nos dê o sentimento da grandeza de nossa missão".

Juscelino propôs o Plano de Metas, cujo lema de campanha, constantemente lembrado durante a sua gestão, foi " 50 anos em 5". O jingle de sua campanha já revela o trabalho de enaltecer sua figura política: "Tem orgulho de falar, Povo Brasileiro, Patriota verdadeiro, tem orgulho de falar meu Brasil, o teu destino está nas mãos de Juscelino, está nas mãos de Juscelino".

As imagens que são reproduzidas no documentário mostram as iniciativas de seu governo, principalmente voltadas à sua proposta de desenvolvimento econômico por meio da criação e expansão da indústria automobilística no Brasil.

As falas in off ressaltam que seu estilo de liderança foi marcado pela estabilidade política, além de envolver uma diferença no jeito de governar: "Seu estilo de improvisações, seu entusiasmo e proximidade com o povo".

Juscelino Kubitschek enfrentou algumas crises políticas, contornadas habilmente pelas qualidades que possuía como conciliador e negociador, qualidades essas ressaltadas pelo documentário: “A habilidade de JK em contornar impasses será testada regularmente $[\ldots]$. O estilo de Juscelino Kubitschek como negociador".

Para exemplificar essas características, o documentário recupera a intermediação que Juscelino exerceu em algumas manifestações envolvendo estudantes e trabalhadores. Foi, também, graças à sua intervenção que Luís Carlos Prestes (PCB) pôde sair da clandestinidade, já que havia um mandato de prisão para ser cumprido por essa liderança comunista.

Outra característica de JK é acrescida no depoimento de Marcos Heusi Neto, ex-presidente da UNE (União Nacional dos Estudantes): “Como governoK. se criou no Brasil um sistema democrático, um sistema político liberal e de confiança, de euforia".

Imagens recorrentes no documentário de JK mostram o presidente dinâmico e arrojado, subindo em tratores que iriam trabalhar na construção de Brasília, a nova capital federal. Voz in off: "Desmontando pessoalmente a floresta, Juscelino fixou a imagem de um Quixote montado num trator".

Foi celebrada uma missa, por ocasião da inauguração do canteiro de obras da nova capital, com a presença de JK e Jango. Voz in off:

“A nova capital também era um cálculo político. Perdida no cerrado, Brasília era uma forma de preservar os poderes da República da pressão direta das massas. Uma maneira de desviar a atenção de sérios problemas econômicos e sociais. Um 
jeito de conseguir a adesão da juventude impaciente. Foi a solução encontrada para isolar os conservadores, os partidários do passado domados de cifras trapaceiras. A nova capital mobilizou ao lado de Juscelino intelectuais, empresários e líderes sindicais. Para essa cidade que simbolizava seu governo Juscelino quis uma arquitetura revolucionária e triunfante".

Depoimento de Oscar Niemeyer, arquiteto de Brasília: "Eassim Brasília se realizou graças a ele. Ele é que teve o entusiasmo, a boa vontade, nos dando a confiança que era necessária".

Voz in off, reforçando o lado decidido e empreendedor:

“Juscelino foi incansável e onipresente. Inaugurou, fiscalizou, controlou de perto as obras. Seu estilo personalista e dinâmico driblou o impossível. [Na avaliação do documentário]. Os intelectuais rebeldes sucumbiram à mística do desenvolvimento e frequentaram o Instituto Superior de Estudos Brasileiros, o Iseb, financiado pelo governo".

Música exaltandoJuscelino Kubitschek: "Juscelino me chamou, eu vou morrer de saudade, mas eu vou. O homem tá chamando".

$\mathrm{O}$ apelo de JK foi atendido; apareceram operários, artistas e intelectuais na cerimônia em Brasília, ainda em construção. Também é reforçada a empreitada de Juscelino no desenvolvimento do processo industrial, principalmente voltado à indústria automobilística, com imagens de produção de fuscas, na Volkswagen e na Ford. Voz in off:

“Durante os anos JK o Brasil teve a ilusão da confiança, o desejo de se internacionalizar, a vontade de se descobrir. Foi a época da bossa nova, dos primeiros filmes do cinema novo, das bienais abstratas, do teatro de Boal e de Guarnieri. A conquista da Copa do Mundo em 1958 desagravou derrotas antigas e desfez a desagradável sensação que, no máximo, o nosso destino era ser $2^{\circ}$ lugar em tudo".
O documentário de Silvio Tendler também mostra problemas nacionais: Nordeste e seca, fome, falta de trabalho, retirantes, flagelados.Quebra-quebra de carreteiros no Rio de Janeiro.Pressões também do exterior - Juscelino Kubitschek rompeu com o FMI e depois foi obrigado a rever o rompimento. Essas imagens servem para mostrar as dificuldades enfrentadas pelo governo JK e possíveis propostas de resolução, como exemplo, a Sudene (Superintendência do Desenvolvimento do Nordeste), embora não seja mostrada sua criação no filme.

Juscelino comandou a caravana de Integração Nacional. É retomada a imagem de JK associado ao Dom Quixote, em cima de um carro Romiseta.

Inauguração de Brasília em 21 de abril de 1960 , com festas e cinejornais: “A partir desta noite, o Brasil começava a ser diferente. O país abandonava uma velha pele, criava um novo ponto de vista. Inaugurava o símbolo do triunfalismo de uma era que se iniciava e, ao mesmo tempo, chegava ao fim".

No documentário é tratada a questão da sucessão de JK: general Henrique Lott e Jango como vice; Jânio Quadros e UDN e Carlos Lacerda. Imagens de campanha, com JQ e o símbolo da vassoura-aparecem os garis da moralidade.

Imagens de JK e JQ assistindo a uma peça teatral, em que a caricatura e a paródia se faziam presentes. Voz in off: "A campanha, em todo caso, refletiu a risonha e tolerante atmosfera do governo JK.Acrítica foi praticada como um direito adquirido. Rir ou discordar não era uma concessão a título precário".

Assim, como no filme de Ana Carolina, também no de Silvio Tendler é apresentada uma personalidade política causadora do desenvolvimento, um político empreendedor, habilidoso, que trazia harmonia ou estabilidade à política e à economia do país.

Um aspecto levantado pelo documentário: "Juscelino começou a se despedir do poder no auge da sua popularidade". Pretendia retornar ao poder em 1965: "Realizou mesmo o inacreditável feito de 
convencer a todos de que a democracia no Brasil estava consolidada".

Ofilme mostra que, por ocasião do golpe de 1964, que derrubou João Goulart, JK apoiou o marechal Castello Branco para a presidência da República, que permaneceu no poder e suspendeu as eleições diretas para o Executivo federal. Renato Archer, histórico membro do PSD, relembrando o que Victorino Freire disse sobre essa posição de JK: "Vais pagar caro por este voto".

Voz in off comenta: "A situação de Juscelino era mais uma vez ambígua. Ele havia apoiado o movimento militar, mas não poderia se eleger em 1965 sem o apoio dos votos do PTB, que acabava de ser excluído do poder".

Logo após o golpe, Juscelino Kubitschek eAdhemar de Barros são cassados, acusados de corrupção. JK não quis ser interpelado pela polícia e naquela ocasião falou em suicídio e morte. Para contornar a situação, o governo militar liberou os passaportes de Juscelino e de sua mulher e eles puderam viajar para o exterior.

No filme se vê Carlos Lacerda, JK e Jango, todos cassados, formando a Frente Ampla para combater o regime militar, mas foram condenados pelo regime. Voz in off:

“Longe da política, Juscelino tornou-se empresário. Redigiu suas memórias. Com ele, a cordialidade desapareceu da vida pública. Sua vocação de tolerância e a generosidade para com os adversários haviam composto seu estilo descontraído do qual o Brasil parece ter perdido a fórmula".

O documentário informa que Juscelino morreu no dia 22 de agosto de 1976, após seu carro ter se espatifado contra uma carreta na Via Dutra. Imagens de uma multidão acompanhando o enterro de JK e, ao fundo, se ouve o Hino Nacional e versos da canção "Peixe Vivo".

Em voz in off um comentário sobre JK:

“Ao contrário de Jânio, cuja carreira passou à história como o argumento destinado a provar que a democracia no Brasil era um sonho impraticável, Juscelino Kubitschek personificou na memória brasileira o oposto. A viabilidade do regime democrático e o respeito incondicional à Constituição”.

\section{JOÃO GOULART: 0 DERROTADO E NÃO COMBATIVO}

O documentário Jango também foi dirigido por Silvio Tendler, em produção de 1984. O filme refaz a trajetória política de João Goulart, o 24으 presidente brasileiro, que foi deposto por um golpe militar nas primeiras horas de $1^{\circ}$ de abril de 1964 . Goulart era popularmente chamado de Jango, daí o título do filme, lançado exatos vinte anos após o golpe. A reconstituição da trajetória de Goulart é feita por meio da utilização de imagens de arquivo e de entrevistas com personalidades políticas.

O documentário centra a sua narrativa na trajetória política de João Goulart, desde seu período como ministro do Trabalho do governo Getúlio até a sua ascensão ao cargo de presidente da República, após renúncia de JQ, o titular do cargo. O documentário destaca a viagem feita por Jango, como vice-presidente, à República Popular da China, em 13 de agosto de 1961. Ele é recepcionado por autoridades e populares chineses, discursa para o Congresso que reúne o Partido Comunista Chinês, visita monumentos históricos e retorna ao Brasil no dia 23 de agosto, um dia antes da renúncia de $\mathrm{JQ}$.

Segundo o depoimento do jornalista Raul Ryff:

"Ele recebeu a notícia em Singapura, no hotel Raffles, pela madrugada. Uma agência telegráfica americana telefonou e queria que ele dissesse alguma coisa sobre a renúncia do Jânio Quadros. Renúncia que ele soube naquele momento da notícia. Ficou surpreendido. Eu me recordo, quer dizer, soube depois, que um dos acompanhantes participantes dessa missão, que era o senador Barros de Carvalho, do PTB, ele logo disse: 'Dr. Jango, vamos abrir uma champanhe 
para comemorar o futuro presidente'. Mas o Jango era um homem muito precavido, um homem muito com o pé no chão. Ele disse: 'Olha, Barros, se você quer tomar champanhe não há inconveniente, vamos mandar buscar champanhe no bar. Agora, não para comemorar a presidência, mas sim em homenagem ao imprevisível",

O filme mostra que para assumir a presidência Jango enfrenta resistências de militares e lideranças empresariais e, após uma série de confrontos e de apoios políticos, principalmente de Leonel Brizola, então governador do estado do Rio Grande do Sul, Goulart consegue ser empossado no cargo, no dia 7 de setembro de 1961, porém com um acordo político que instituía um sistema parlamentarista. O primeiro-ministro que assumiu esse cargo foi Tancredo Neves.

Segundo áudio do documentário, “[...] Jango assumiu a presidência da República e anunciou que seu governo pretendia marcar uma nova independência do Brasil”.

Os planos de governo de Jango incluíam reformas de base, como a reforma agrária, reforma tributária, reforma urbana, nacionalizações de empresas, renegociações das dívidas externas, dentre outros aspectos. No discurso de posse de João Goulart, suas palavras marcam seu estilo de governar e traços de sua liderança política:

"A minha investidura, embora sob a égide de um novo sistema, consagra respeitoso acatamento à ordem constitucional .

Subo ao poder ungido pela vontade popular, que me elegeu duas vezes Vice-Presidente da República e que, agora, em impressionante manifestação de respeito pela legalidade e pela defesa das liberdades públicas, uniu-se, através de todas as suas forças, para impedir que a sua decisão soberana fosse desrespeitada.

Considero-me guardião dessa unidade nacional, e a mim cabe o dever de defendê-la, no patriótico objetivo de defendê-la para a realização dos altos e gloriosos destinos da Pátria Brasileira.

[...] Tudo fiz para não marcar com o sangue generoso do povo brasileiro o caminho que me trouxe a Brasília.

Sabem os partidos políticos, sabem os parlamentares, sabem todos que, inclusive por temperamento, inclino-me mais a unir do que a dividir, prefiro pacificar a acirrar ódios, prefiro harmonizar a estimular ressentimentos.

Promoveremos a paz interna, paz com dignidade, paz que resulte da segurança das instituições, da garantia dos direitos democráticos, do respeito permanente à vontade do povo e à inviolabilidade da soberania nacional".

O documentário reforça a ideia de que Jango era a "herança política de Getúlio" e que ambos tinham "o sentimento nacionalista e o compromisso com a justiça social, razões trágicas do destino comum destes dois homens". Na avaliação do documentário, “João Goulart, aos 36 anos, representou o desejo de Vargas de injetar sangue novo na política brasileira [...]. Jango com as reformas fez o Brasil viver sua utopia”.

Um plebiscito foi convocado no ano de 1962 para que os cidadãos brasileiros se manifestassem contra ou a favor do sistema parlamentarista, pois nenhum político aceitava a imposição desse controle.

A oposição começou a se firmar com a criação do Ibad (Instituto de Ação Democrática), do Ipes (Instituto de Pesquisas e Estudos Sociais) e da ESG(Escola Superior de Guerra), e ganha novo impulso para realizar oposição ao governo de Goulart. A propaganda desses institutos acusava Jango de ser "fomentador de greves, articulador da luta de classes e inimigo do capitalismo".

O filme mostra que os confrontos se acentuaram por ocasião da Rebelião dos Sargentos, do movimento dos Fuzileiros Navais. Setores da esquerda consideravam que JG não estava exercendo o seu cargo como havia prometido, e setores do Congresso Nacional também estavam descontentes com a atuação do governante. Com isso, Jango ficou isolado politicamente e, para recuperar bases de apoio, fazia comícios e começava a legislar em praça pública. O Comício da Central do Brasil, realizado no dia 13 de mar- 
ço de 1964, marcou o começo do confronto final e de sua derrubada do poder. A Marcha da Família, com Deus e pela Liberdade, que combatia o comunismo e defendia um civismo baseado no trinômio Deus, Família e Propriedade, foi realizada em São Paulo, e depois o movimento se espalhou para outros estados e cidades brasileiras.

O jornalista Raul Ryff comenta:

“O comício da Central é uma espécie de tentativa para acelerar o processo das reformas. E muita gente o aconselhou que não fizesse aquele comício. Que seria, sob certos aspectos, uma provocação. E que ele não anunciasse aquelas reformas, muitas que talvez não fossem possíveis de realizar. Aí o Jango, eu me lembro bem, declarou: 'eu não tenho problema em ficar ou não no governo, o meu problema é que tenho que realizar essas reformas. Eu prefiro cair e cair de pé",.

Com exceção de uma parte do discurso proferido no Comício da Central do Brasil,o documentário quase não reproduz discursos de João Goulart. Limita-se a mostrar imagens do político em comemorações, encontros políticos e em palanques, discursando.

$\mathrm{Na}$ Central do Brasil, discursando de improviso:

"Hoje, comoalto testemunho da nação, com a solidariedade do povo reunido na praça, que só ao povo pertence, o governo, que é também o povo, e que também só ao povo pertence, reafirma seus propósitos inabaláveis de lutar com todas as suas forças pela reforma da sociedade brasileira”.

No filme, imagens das Forças Armadas, através da atuação do Exército, mostram o avanço sobre a cidade do Rio de Janeiro, não encontrando resistências. Jango segue para Brasília e depois para Porto Alegre, mas o golpe estava acontecendo.

Leonel Brizola tenta reverter a situação golpista, dialogando com o comandante do III Exército, mas deixa a decisão final dessa reunião com o presidente João Goulart, que “decidiu que não houvesse a resistência porque considerava que seria um tributo de sangue demasiadamente grande que o povo brasileiro teria que pagar para restaurar os seus direitos".

Complementarmente ao filme, cabe observar que o golpe de 1964 foi articulado por militares e elites civis, que já transitavam juntas em espaços como a ESG (Escola Superior de Guerra) e o Ipes (Instituto de Pesquisa Econômica e Social) e já haviam tentado impedir a posse de João Goulart em 1961, por ocasião da renúncia de Jânio Quadros ao cargo de presidente da República. O golpe foi dado em nome da democracia, para combater o avanço do comunismo, a desagregação das instituições, o restabelecimento da hierarquia militar e inviabilizar a implantação das reformas de

\section{Cartaz do filme Jango, de Silvio Tendler}

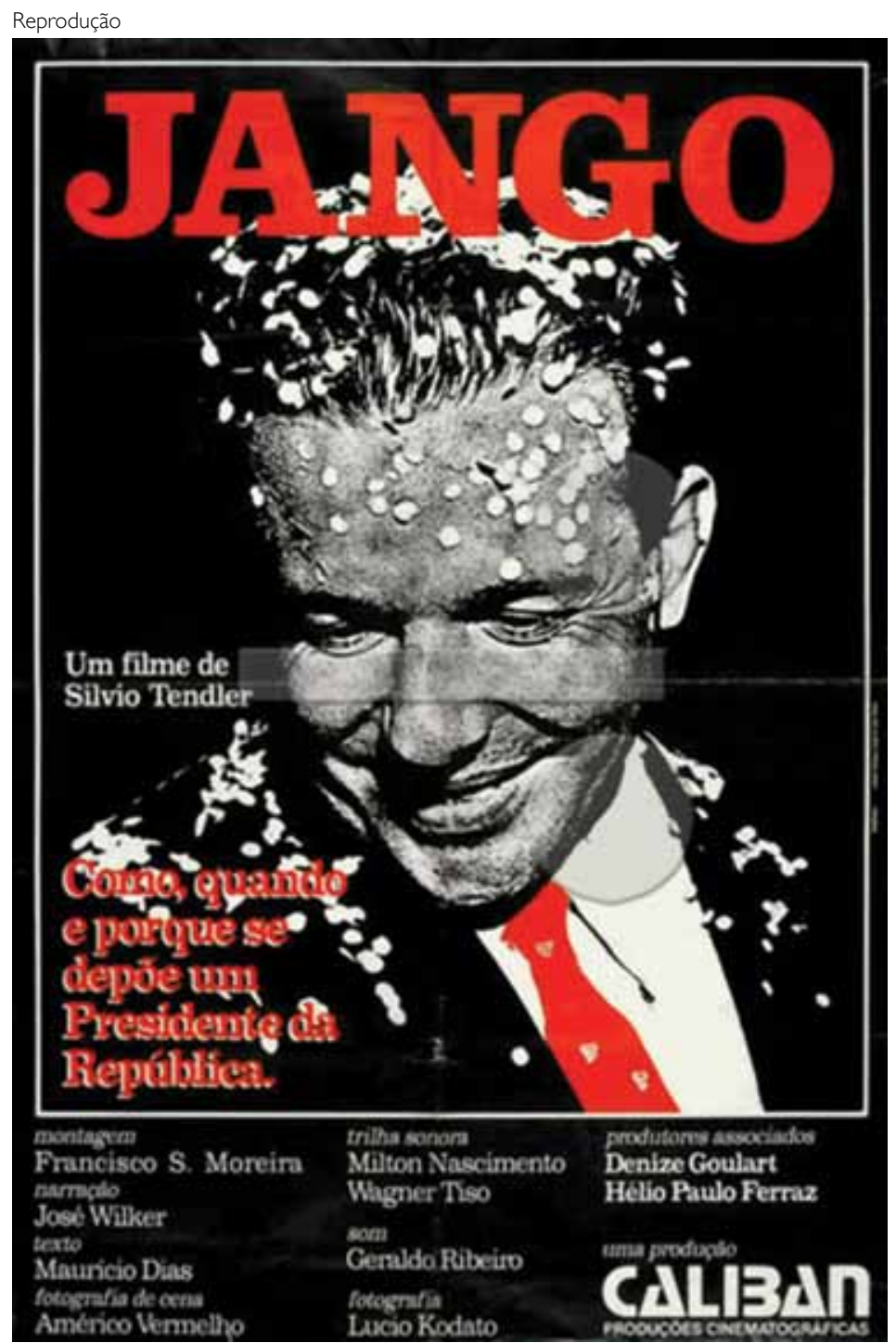


base, propostas pelo governo de Goulart.

Voltando ao filme, Auro de Moura Andrade, então presidente do Congresso Nacional, afirma, em plenário, que o presidente "deixou a sede do governo, deixou a nação acéfala" e declara "vaga a presidência da República”. Ocorrem manifestações contrárias ao golpe no plenário. Leonel Brizola repudiou o golpe e resistiu, mas Jango decidiu que não deveria haver resistências porque nãoqueria que ocorresse derramamento de sangue.

O áudio procura explicar o golpe sofrido por Jango:

"Jango pretendia reformar a face do capitalismo brasileiro, diminuindo as desigualdades sociais, dando-lhe um aspecto mais humano, menos selvagem. Entre seus aliados, muitas vezes seus objetivos eram confundidos com a intenção de acabar com o capitalismo. Outras tantas, que não pretendera acabar com o capitalismo. Tinha que compor sua estratégia de ação lutando ainda contra o desconforto pessoal de ser o presidente de um país pobre”.

Cabe observar, adicionalmente ao filme, que a intervenção militar colocava-se a ser breve e somente cobriria o mandato do presidente deposto (1960 a 1965). O papel dos militares naquele momento seria o de eliminar as lideranças políticas, sindicais e populares que se identificavam com aquela proposta do governo de Goulart. Posteriormente seriam realizadas novas eleições presidenciais e o poder retornaria aos civis. Mas não foi isso que aconteceu. Por problemas internos de facções diferenciadas dos militares, a opção foi continuar no poder por mais algum tempo, e esse período somente terminou em 1985, com a eleição de um civil para a presidência da República. Tancredo Neves foi eleito presidente, sem o voto direto, pelo Colégio Eleitoral, composto por senadores e deputados federais e com a aquiescência dos militares.

O filme, já no seu final, mostra que no dia 2 de abril de 1964 Jango parte para São Borja e de lá para o exílio, no Uruguai. No

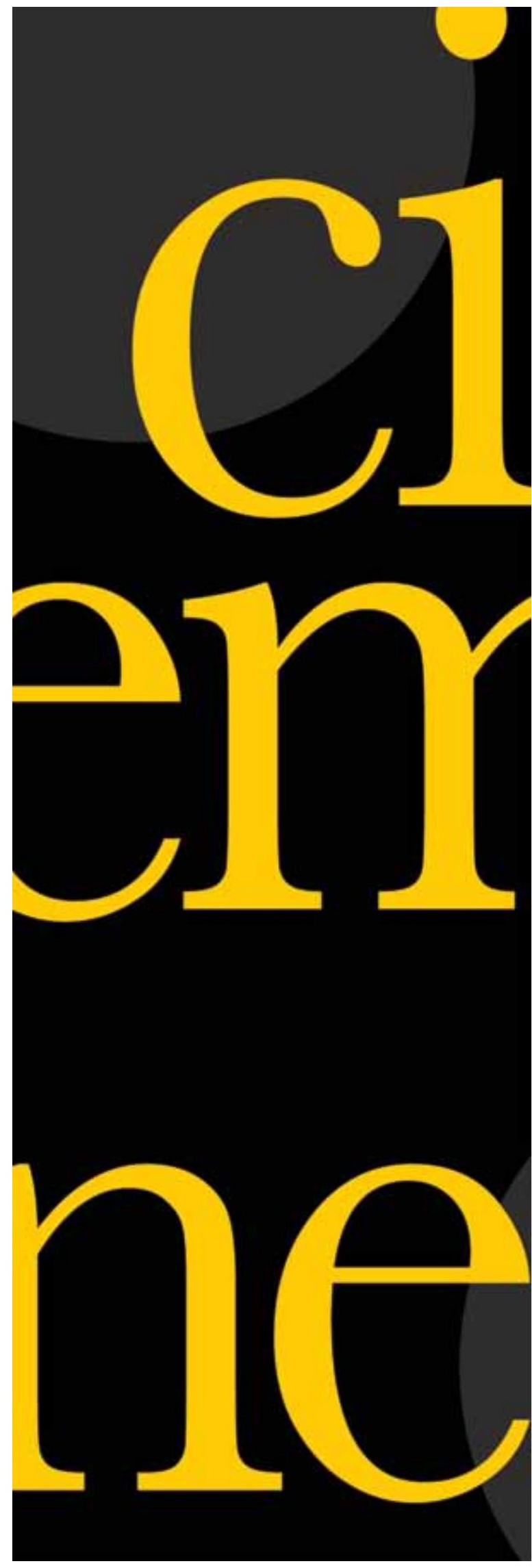


pela ditadura militar, em pleno momento de abertura política, se dá a partir de um material de base (arquivos provenientes de agências de notícias e de cinejornais, sobretudo) que foi tomado segundo 'a ótica do poder', como nota tão bem Jean-Claude Bernardet, a respeito de Os Anos JK; mas sobretudo por causa da maneira como esses arquivos estão montados e comentados - a presença de uma voz off segura e constante 'determina significações e exerce poder sobre o espectador', engendrando uma espécie de fluxo que atende, grosso modo, a uma ordenação cronológica, que acaba por se confundir com um pretenso fluxo da história - o que impede que se veja a escritura da história como resultado de decisões singulares e situadas, e não como um processo contínuo e orgânico em que os fatos se articulam numa cadeia de causalidade que o próprio filme internalizaria" (Mesquita, 2010, pp. 2-3).

Silvio Tendler, diretor dos filmes Jango e $J K$, iniciou a sua carreira artística nos anos 1970 e se especializou em realizar documentários. Já retratou vários personagens políticos, como João Goulart (1984), Juscelino Kubitschek (1980), Glauber, o filme (2003), Carlos Marighella (2001), Josué de Castro (1994), Milton Santos (2006) e Tancredo Neves (2010).

Na sua avaliação, “[...] o documentário tem que acontecer à medida que ele vai sendo construído, ele é investigativo. Roteiro de documentário é isso, é um filme bem pautado" (Caros Amigos, março de 2011, p. 16).

Segundo Silvio Tendler:

"[...] os documentários de Jango e de JK devem ser compreendidos como sonhos interrompidos. Na verdade, as pessoas falam que eu sou o cineasta dos vencidos, porque eu fiz sobre o Jango, o JK, mas tenho um amigo meu,oArnaldo Carrilho, embaixador do Brasil na Coreia do Norte, que é um cara absolutamente genial, é um filósofo e ele sacou a minha obra, o que unia os meus filmes com personagens tão diferentes em si. Ele sacou que são personagens que saí- ram de cena antes de cumprir a missão, por conta dos sonhos interrompidos. O Jango foi o único presidente brasileiro a morrer no exílio, foi deposto, não concluiu o governo. Juscelino Kubitschek tinha o sonho de voltar em 65, foi cassado, nunca voltou... sou 'o cineasta dos sonhos interrompidos" (Caros Amigos, março de 2011, p. 17).

Os documentários sobre JK e Jango corroboram a historiografia recente. As reconstruções das vidas dos presidentes retratam e servem para construir imagens de lideranças políticas que vivenciaram períodos conturbados na história do Brasil.

Nesse sentido, considerando-se Ana Carolina e Silvio Tendler, cabe já antecipar a força do cinema (seja como peças publicitárias produzidas pelo governo, seja como obra de pensamento produzido por intelectuais cineastas que recuperam a história) como uma mídia fundamental para a construção da imagem pública de um governante e de seu governo. Desde Getúlio Vargas, JK e Jango, até os dias atuais, vê-se uma política modernizada, que passa a se instrumentalizar tendo em vista ampliar a governabilidade. Rádio, cinema, imprensa escrita e, mais tarde, televisão serão requisitados por governantes para visibilizar os atos de seus respectivos governos e propiciar a construção ideológica das feições (auto)desejadas pelo governo político.

Nessa direção, cabe observar tanto o recurso político do uso da morte/perda do corpo do governante, quanto os trágicos destinos de Getúlio Vargas, Juscelino e Jango, como semelhanças entre os três governantes.

Muitos documentários e até um filme de ficção foram produzidos sobre o retirante, o metalúrgico, o líder sindical e o candidato à presidência da República Luiz Inácio Lula da Silva. A sua história de vida permite essas incursões e ajuda a reforçar a figura carismática de Lula. Está aí outra liderança política potente para atrair cineastas, cujos filmes merecem também análises futuras para compreender como se deu a construção dessa imagem política. 


\section{BIBLIOGRAFIA}

ALMEIDA, Cláudio Aguiar. "O Filme do Documentário e a Construção da História: Getúlio Vargas, de Ana Carolina", in Cadernos de Ciências Humanas - Especiaria, v. 10, n. 17, jan.-jun./2007, pp. 41-56.

ANDRADE, Auro Moura. Um Congresso contra o Arbítrio: Diários e Memórias. Rio de Janeiro, Nova Fronteira, 1985.

BANDEIRA, M. O Governo João Goulart - as Lutas Sociais no Brasil 1961-1964. Rio de Janeiro, Civilização Brasileira, 1977.

BENEVIDES, M. O Governo de Kubitschek - Desenvolvimento Econômico e Estabilidade Política. Rio de Janeiro, Paz e Terra, 1976.

. V. "O Governo Kubitschek: a Esperança como Fator de Desenvolvimento", in O Brasil de Juscelino Kubitschek. Rio de Janeiro, Editora FGV, 2002.

BERNARDET, Jean-Claude; RAMOS, Alcides Freire. Cinema e História do Brasil. São Paulo, Contexto, 1988.

CAROS AMIGOS, março de 2011.

CHAIA, Vera. A Liderança Política de Jânio Quadros (1947-1990). Ibitinga, Humanidades, 1991. ."Lideranças Políticas e Cinema: a Imagem do Poder", in Revista Ponto e Vírgula. Publicação do PEPG em Ciências Sociais da PUC-SP, n 9, 2011. Disponível em: www.pucsp.br/ponto-e-virgula.

DREIFUSS, René A. 1964: A Conquista do Estado. 7ạ ed. Petrópolis, Vozes, 2008.

GOMES, Wilson. Transformações da Política na Era da Comunicação de Massa. São Paulo, Paulus, 2007.

HIPPOLITO, L. PSD - de Raposas e Reformistas. Rio de Janeiro, Paz e Terra, 1985.

MESQUITA, Claudia. "Retratos em Diálogo: Notas sobre o Documentário Brasileiro Recente", in Novos Estudos - Cebrap. n 86, São Paulo, mar./2010.

SOUZA, E. M. de. "Juscelino Kubitschek Reinventa o Moderno", in W. M. Miranda (org.). Anos JKMargens da Modernidade. São Paulo, Imprensa Oficial, 2002.

\section{Filmografia}

CAROLINA, Ana. Getúlio Vargas. Brasil, Zoom Cinematográfica, 1974.

TENDLER, Silvio. Os Anos JK: Uma Trajetória Política. Brasil, Caliban Produções Cinematográficas, 1980.

.Jango. Brasil, Caliban Produções Cinematográficas/Rob Filmes, 1984. 